\title{
O olhar da História do Olho: notas sobre um objeto lacaniano
}

\author{
Renata Damiano Riguini* \\ Ilka Franco Ferrari**
}

\begin{abstract}
Resumo
Neste artigo partimos da novela História do Olho, de Georges Bataille em direção à noção de objeto escópico em Lacan. A História do Olho nos mostra, entre outras articulações, as relações e disjunções do olho e do olhar na sexualidade de dois adolescentes. Em Lacan encontramos uma passagem que se refere a esta mesma novela. Ali o psicanalista trabalha a noção de objeto olhar e pulsão escópica usando seu conceito de objeto $a$, e conclui que somos olhados no espetáculo do mundo. Concluímos que Bataille opera com um saber fazer com o olho, e mostra que não é só o Outro que nos olha de onde não nos vemos, mas que o objeto também olha. $\mathrm{O}$ objeto olha e revira a imagem ao avesso: é o real que retorna para uma nova História.
\end{abstract}

Palavras-chave: Objeto $a$. Olhar. Pulsão escópica.

\section{The Gaze of The Story of The Eye: Notes About a Lacanian Object}

\begin{abstract}
In this article, we start from the novel Story of the Eye towards the concept of scopic object. The book shows us, among other connections, relations and disjunctions of the eye and the gaze at the sexuality of two teenagers. In Lacan we find a passage that refers to the same novel. There the psychoanalyst works with the concept of object gaze and scopic drive using his concept of object $a$, and concludes that we are looked at in the world spectacle. We conclude that Bataille operates with a know-how with the eye, and shows that it is not only the Other that looks at us from where we do not see, but that the object also does. The object looks and rolls the image inside out: the real which returns for a new Story.
\end{abstract}

Keywords: Object $a$. Gaze. Scopic drive.

Recebido em: 01/11/2016

Aceito em: 09/04/2018

\footnotetext{
* Pontifícia Universidade Católica de Minas Gerais (PUC Minas). Pós-doutoranda no Programa de Pós-Graduação em Psicologia da PUC-Minas. Doutora em Psicologia pela PUC-Minas, Mestre em Teoria Psicanalítica pela UFMG. Psicanalista.

** Pontifícia Universidade Católica de Minas Gerais (PUC Minas). Doutora em Psicologia pela Universidade de Barcelona. Professora no Curso de Graduação e no Programa de Pós Graduação em Psicologia da PUC-Minas. Aderente da Escola Brasileira de Psicanálise, Minas Gerais.
} 
Em 1966, no Seminário 13 O Objeto da Psicanálise (1965-66), Lacan, entre outras referências da literatura e da pintura, nos convida a ler a História do Olho (2003), novela escrita por Georges Bataille. Ele destaca naquele ano: "Somos psicanalistas, com o que temos de nos haver? Com uma pulsão que se chama pulsão escópica". (LACAN, 1965-66, aula 20). Isto porque, segue ele, uma análise está centrada em torno da janela da fantasia fundamental, na medida em que, ao ser suportada pelo objeto $a$, ela integra a existência do sujeito que olha e é visto. Para avançar neste sentido, continua Lacan, teremos que cernir o objeto $a$ que se chama olhar.

Neste artigo buscaremos esclarecer alguns pontos sobre o objeto olhar e a pulsão que o circunscreve, seguindo a pista lacaniana que indica a História do Olho (2003) como rota. Isso considerando essencial para a práxis da psicanálise a construção e definição do objeto chamado pelo próprio Lacan de sua invenção, o objeto $a$, objeto lógico que organiza a subjetividade por meio da fantasia de cada sujeito. O trajeto proposto, portanto, é a tentativa de um resgate das consequências da História do Olho (1928/2003), nas formalizações lacanianas. O que nos ensina Georges Bataille sobre a pulsão escópica? O que nos ensina a História do Olho sobre o olhar enquanto objeto?

Georges Bataille não foi só contemporâneo de Lacan, mas seu amigo. Os dois dividiram alguns espaços, frequentaram o surrealismo e as aulas de Kojève e, sobretudo, dividiram também interesses teóricos. Encontramos muitas coincidências nas obras dos dois autores e, ao mesmo tempo, quase nenhuma menção de um ao outro. Conforme estudo realizado, ${ }^{3}$ mesmo entre seus leitores, não encontramos muitos traços deste encontro. Nessa convergência dos dois autores encontramos a afirmação contundente de Assandri (2007, p.7) de que há um enorme "pedaço" de Bataille em Lacan, que não é fácil discernir. Ou seja, que Georges Bataille não está contido somente em uma citação de Lacan, embora a citação do Seminário 13 tenha nos servido como orientadora e condensadora no percurso realizado, principalmente em momentos de impasse. Faz-se necessário começarmos esta articulação pela citação de Lacan.

Há toda uma história do olho, é o caso dizê-lo. Aqueles aqui que têm as orelhas abertas ao que pode ser informação latente, sabem a que faço alusão ao falar da História do Olho. É um livro publicado anônimo, por um dos personagens mais representativos de uma certa inquietação essencial de nossa época e que passa por uma novela erótica. A História do Olho é rica por toda uma trama bem feita para recordarmos, se pode-se dizer, o encaixe, a equivalência, a conexão entre eles de todos os objetos e sua conexão central com o órgão sexual" (LACAN, 1966, aula 20, em 01/06/1966). ${ }^{4}$

Para Assandri (2007), em 1966, à medida que Lacan tomou a pulsão escópica como ponto central, a História (1928/2003) de Bataille apareceu como referência. Outro ponto significativo é ressaltado por Assandri (2007): Lacan chama a História do Olho (2003) de novela erótica, mas não sem incômodo. Ele diz que o livro "passa por" uma dessas novelas que são conhecidas como eróticas. Mas, nesta passagem do seminário, Lacan menciona a História do Olho ao falar do objeto estranho, tal como Freud o enunciou em "O Estranho" (1919), a partir do conto "O Homem de Areia", de E.T.A. Hoffmann (1817). Desta forma, ao nosso entender, Lacan aproxima a novela de Bataille ao conto fantástico. Ele destaca o estranhamento do sujeito frente ao olho cortado e cego que aparece na novela de Bataille. O olho, nesta narrativa, é capaz de produzir um encontro com o real na medida em que opera uma ruptura com o familiar, quando pode ser substituído por objetos insuspeitos ou deslocado para lugares inadvertidos.

\footnotetext{
3 Este artigo é fruto da pesquisa de doutorado, $\mathbf{O}$ olho obsceno:Considerações sobre o objeto olhar em Georges Bataille e Jacques Lacan (RIGUINI, 2015), que contou com bolsa CAPES e com o Fundo de Incentivo à Pesquisa, da PUC Minas, FIP. Ali listamos as referências encontradas sobre este ponto.

4 "Hay toda una historia del ojo, es el caso de decirlo. Aquellos que tienen acá la oreja abierta a la que puede ser información larvada, saben a que hago alusión al hablar de la historia del ojo. Es un libro publicado anónimo, por uno de los personajes más representativos de una cierta inquietud esencial de nuestra época y que pasa por una novela erótica. La historia del ojo es rica por toda una trama bien hecha para recordarnos, si se puede decir, el encaje, la equivalencia, la conexión entre ellos de todos los objetos y su conexión central con el órgano sexual". (LACAN, 1966)
} 
Vale acrescentar que Assandri (2007) considera que Bataille não tocou na cisão do olho e do olhar, tal como Lacan o fez no Seminário 11 (1998 [1964]). De fato, quando falamos em Bataille e em Lacan, falamos de campos e apreensões diferentes, inclusive o léxico dos dois autores é bem distinto. Para Assandri (2007, p.148) trata-se, ainda assim, de uma apropriação, por parte de Lacan, daquilo que Bataille deixa "a céu aberto com a história do olho e entre seus papéis sobre o mito do olho pineal." 5

\section{A História do Olho: a destruição da beatitude humana}

Neste item, destacaremos alguns pontos da novela batailliana que entendemos como imprescindíveis para a leitura que faremos. ${ }^{6}$ A História do olho (2003), primeiro livro de Georges Bataille, é uma novela estranhamente idílica e, ao mesmo tempo, tem um caráter de pleno desvario, como definiu Leiris (2003). Segundo Moraes (2003), o livro foi escrito em circunstâncias existenciais. Bataille estava prestes a completar trinta anos e em frequente estado de crise, pois, se por um lado tinha uma vida completamente desregrada de jogo, bordéis, orgias e bebidas, de outro era atormentado por inquietações filosóficas profundas, que marcavam sua solidão e angústia. Este estado crescia junto com suas obsessões, associadas à violência sexual e ao êxtase religioso. Foi assim que Bataille, ainda antes de conhecer Lacan, se submeteu a uma análise por mais ou menos dois anos com Adrien Borel o que, segundo ele, o colocou em condições de escrever.

A obra de 1928 (1928/2003) é uma narrativa crua e mordaz da angústia relacionada à descoberta da sexualidade, à presença do mal e da morte pelos seus personagens. A morte aparece durante toda a narrativa como saída para um erotismo trágico. É um encontro com o corpo próprio, com o outro sexo, ou com o sexo do outro, onde os adultos não são permitidos em cena. Bataille segue usando uma narrativa objetiva, realista ao extremo, que faz contraste com o irreal das cenas relatadas.

A História do Olho, como outras novelas de Bataille, é contada a partir de um narrador masculino, anônimo, em primeira pessoa. Este narrador é um adolescente, transtornado pelo encontro com outra adolescente. Esta jovem, Simone, ávida por tudo que possa contornar os sentidos e a razão, busca o que está ligado à sexualidade mais profunda: o sangue, a urina, as lágrimas, o grito, o terror súbito, o crime, a carne, ou seja, tudo que possa destruir a beatitude humana.

Bataille (2003, p. 23) inicia a história com o narrador dizendo: "Fui criado sozinho e, até onde me lembro, vivia angustiado pelas coisas do sexo". Aos dezesseis anos conhece Simone, e logo se precipitam em uma relação de cumplicidade: "comecei a me dar conta de que ela partilhava minha angústia, bem mais forte naquele dia em que parecia estar nua sob o avental". Logo começam os jogos sexuais dos adolescentes. Brincadeiras com leite e ovos, principalmente os ovos, dadas suas afinidades fórmicas com o globo ocular, e com a própria palavra olho, por homofonia, tomavam as tardes de verão dos jovens. Em uma espécie de retorno a um erotismo polimorfo perverso, próprio das descobertas e invenções infantis, eles se entregam aos mais altos desvarios, a fim de alcançar mais e mais deste gozo.

Logo em seguida, a estranha e meiga Marcela se junta ao casal adolescente. Marcela é a mais pura e delicada das amigas de Simone e do narrador. Os três entram em um frenesi erótico e obsceno, marcado por uma tempestade com fortes estrondos, relâmpagos, barulhos do mar, que servem de

5 Em especial, destacamos dois textos: "O ânus solar" (1927), um dos primeiros textos de Bataille e "O olho pineal", coletânea de textos difíceis de serem datados, acredita-se que forma escritos, em sua maioria, entre 1930-36. O tema do olho percorre toda a obra batailliana.

6 Uma leitura mais minuciosa da História do Olho (2003) também foi feita na tese de doutorado intitulada "O olho obsceno:Considerações sobre o objeto olhar em Georges Bataille e Jacques Lacan” (RIGUINI, 2015) que deu origem a este artigo. 
metáfora para a violência e fúria dos corpos que se agarravam e se exploravam. A fusão com o cosmos e as metáforas da natureza são temas recorrentes na História de Bataille. Muitas vezes, tais tópicos beiram a ausência de sentido total e buscam mostrar, assim, o estado de espírito em que se precipitam os personagens, bem como contagiar o leitor. A devassidão é, na novela, um destino e uma exigência dados pela natureza, e levam a um processo de despersonalização.

No capítulo seguinte as brincadeiras continuam e, assim que os protagonistas encontram Marcela, a dupla a manipula para levá-la a uma festa na casa de Simone, com outros colegas. O que vem a seguir é um mar de orgias, uma desordem desvairada. Marcela que parecia ter se deparado com a própria morte, escondeu-se no armário para se masturbar. Desse armário agora era possível escutar gritos inumanos e grunhidos bestiais. Os adolescentes, do lado de fora, riam de Marcela que perde a razão durante o caos de corpos desnudos. Marcela se trancou ali, e só saiu mais tarde quando foi retirada pelos pais e pela polícia. Esta interrupção, no texto e na cena, conecta erotismo e loucura. A moça angelical enlouquece depois do ataque a que foi submetida.

Marcela é internada e o casal passa uma fase apática, sem desejo, a esperar por ela. O sexo já não é possível sem aquela cujos gritos excitavam os desejos turvos do narrador e de Simone. Eles evitam sequer aludir suas obsessões ou mesmo suas fantasias, enquanto se preparavam para resgatar Marcela do hospital psiquiátrico em que foi internada. E assim o fizeram. Marcela, parecendo confusa, acreditava que estava sendo levada para se casar com um fantasiado salvador. Ao chegar à casa de Simone, reconhece o armário onde se escondeu um dia. Logo, percebe que o narrador foi seu algoz, e se desespera, pondo-se aos berros, enlouquecida. A dupla deixa a moça sozinha para se acalmar, mas, quando voltam, ela está enforcada, morta dentro do já familiar armário. Dando livre curso às inclinações necrófilas, o casal deixa as brincadeiras e faz amor pela primeira vez.

O narrador e Simone, logo depois deste fato, fogem para Espanha onde encontram um amigo da moça, Sir Edmond. O trio gostava de assistir touradas, e particularmente Simone se excitava. Certo dia, já não lhes satisfaziam as tormentas e horrores típicos destes espetáculos. Simone pediu a Sir Edmond os testículos crus do primeiro touro a se apresentar, assim que ele morresse, e ele atende a seu pedido. Ela come um deles enquanto introduzia o segundo na vulva. No mesmo momento, durante o espasmo de Simone, Granero, o grande toureiro da noite, é acuado contra a cerca e um touro lhe desfere três golpes, arrancando-lhe um olho que permanece espetado em seu chifre. Neste instante, o narrador em tom confessional diz sentir o que espera sentir a algum tempo: "por um átimo" (BATAILLE, 2003, p. 71), sente a presença de Marcela.

O trio decide viajar para Sevilha. Desta vez foram a uma igreja, e um padre recebeu a visita dos três amigos. A decadência do jovem padre começa no confessionário. Simone faz do espaço sagrado uma espécie de câmera escura, "reveladora dos poderes do olho" (TEIXEIRA, 2005, p.46), já que a relação com o olho é resgatada pela provocação de Simone ao exibir seu sexo ao santo homem. De fato, frente ao sexo-Medusa exposto de Simone o padre fica siderado, mudo. Ele foi amordaçado, imobilizado, espancado e enforcado.

Simone pede a Sir. Edmond que arranque o olho do cadáver. Ela compara o olho arrancado a um ovo, como qualquer ovo de suas brincadeiras sexuais, para que pudesse se divertir com ele. O pequeno globo branco se mistura aos corpos nus e febris de Simone e do narrador, até que a moça resolve introduzi-lo na vagina. Simone exige o olho do padre para destruí-lo. O olho faz-se objeto em um jogo extravagante e luxurioso, torna-se objeto sexual ritualizado, consagrado, onde a reversibilidade olho-ovo. As metáforas do olho são transmutações, reversibilidade instantânea, que acontecem em momentos de báscula, em um piscar de olhos, entre a vida e a morte.

Neste ínterim, os personagens se entregam a um frenesi sagrado, que Bataille demonstra através da escrita por meio de rupturas de tom, oximoros, paradoxos. Tais artifícios suscitam no leitor mal estar e até mesmo dor. Entre linhas e pontos de suspensão, no espaço branco do olho, o texto faz 
silêncio, deixa cair o sentido a favor do estupor. Bataille pretende conduzir o leitor à noite da ausência de Deus e da razão, onde o pensamento se desvincula das palavras.

Aqui termina a novela, mas Bataille não termina o livro. Acrescentou à História alguns fragmentos onde, desta vez, é ele o próprio, em primeira pessoa, na voz do pseudônimo Lord Auch, quem narra as lembranças associadas aos temas da novela. Não adentraremos nesta parte entendendo que o já colocado nos dá elementos para pensarmos no objeto olhar lacaniano tal como nos ocupamos,

\section{Freud e a pulsão escópica como constituinte de Eros}

Sabemos que Freud (1910/1996) fala da pulsão sexual que se utiliza do olhar, a escotofilia, como se pode ler no ensaio de 1910, "A Concepção psicanalítica da perturbação psicogênica da visão". Ali ele utiliza a cegueira histérica como exemplo de perturbação psicogênica visual, e explica que, para a psicanálise, esse é um sintoma, resultado das falhas no recalque. O recalque, explica Freud, é o mecanismo responsável por manter, no inconsciente, certos grupos de ideias indesejáveis à consciência.

Naquele contexto Freud (1910/1996, p.223) pondera que as coisas não seguem tão tranquilamente nos domínios do inconsciente. A pulsão interfere demasiado na vida ideacional do sujeito. Ele descobre que cada pulsão, aqui Freud fala em pulsão de auto-conservação versus pulsão sexual, procura manifestar-se por meio de ideias já ativas, "ideias em harmonia com seus objetivos". Ora, os interesses dessas duas pulsões, amiúde entram em conflito. A cegueira histérica é, desta forma, uma expressão da luta entre as pulsões.

Tanto as pulsões sexuais como as pulsões do eu, têm, em geral, os mesmos órgãos e sistemas de órgãos á sua disposição. O prazer sexual não está apenas ligado aos genitais. A boca serve tanto para beijar como para comer e para falar; os olhos percebem não só as alterações do mundo externo, que são tão importantes para preservação da vida, como também as características dos objetos que os fazem ser escolhidos como objetos de amor. (FREUD, 1910/1996, p.223).

Esta é uma relação de um órgão com uma exigência pulsional que recai sobre ele. O olho servirá à visão, portanto ao eu e a sua preservação, e também a olhar/ser olhado, enquanto fonte de prazer. Como dirá mais tarde Lacan (1964/1998, p. 100): “A maravilha é que de seu órgão, ${ }^{7}$ o organismo pode fazer qualquer coisa". Para Freud, se as pulsões escópicas atraíram para si a força defensiva das pulsões do eu, a ponto de serem recalcadas, haverá uma perturbação da relação do olho com o ato de ver.

O eu perde a partida e fica à disposição da pulsão sexual recalcada. O órgão, segundo Freud, é levado a um exagero de sua função erógena, ou seja, o olho é tomado na dialética do falo, e logo esta pulsão exacerbada será recalcada. Neste processo do recalque da escotofilia, melhor dizendo, em suas falhas, aparecem, como sintomas, as perturbações psicogênicas da visão.

O que Freud já nos mostra, e que nos interessa neste percurso, é a cisão, no aparelho psíquico do sujeito, que incide no corpo biológico, nesse caso no olho, e o divide em pulsão, olhar. Sua satisfação não é obtida, claro está, pela manipulação do órgão, mas na relação da visão com os significantes, por sua propriedade significante: tocar com os olhos, comer com os olhos, desnudar alguém.

Em seus Três ensaios sobre a teoria da sexualidade Freud (1905/1996) tratou da pulsão de ver

7 Freud e Lacan usam a palavra órgão de forma diferente. Freud fala do olho, por exemplo, como órgão da visão, ou seja, Freud tem uma concepção de que cada órgão tem sua função demarcada no corpo a priori. Lacan fala de qualquer órgão como não tendo uma função biológica, mas que a pulsão virá para fazer o órgão e sua função, assim como acontece com o pênis. (LACAN, 1998 [1964]). 
e ali destacou o papel da pulsão escópica que, enquanto parcial, portadora de novos alvos, aparece em pares de opostos: “toda perversão 'ativa', portanto, é acompanhada por sua contrapartida passiva: quem é exibicionista no inconsciente é, também, ao mesmo tempo, voyeur" (FREUD, 1905/1996, p. 158). A zona erógena em jogo nesta pulsão é o olho, ou seja, o olho se comporta como uma parte do aparelho sexual.

$\mathrm{Na}$ histeria, esses lugares do corpo e os tratos da mucosa que parte deles transforma-se na sede de novas sensações e de alterações na inervação - e mesmo de processos comparáveis à ereção - tais como os próprios órgãos genitais diante das excitações dos processos sexuais normais (FREUD, 1905/1996, p.160).

O voyerismo e o exibicionismo são assim, para Freud, uma manifestação espontânea na infância que, no entanto, pode se perpetuar na vida adulta e se tornar um sintoma mórbido. A pulsão de ver, apesar da preponderância das zonas erógenas enquanto fontes de prazer, se apresenta desde o início da vida infantil, destacada das atividades sexuais erógenas.

Vale ainda comentar que, para Freud, não há uma fase escópica, tal como se fala de fase anal e oral. Quinet (2002) destaca que, se Freud não deu um lugar específico na descrição do desenvolvimento pulsional para o escópico, em contrapartida lhe conferiu uma função constituinte da sexualidade: a impressão visual é a responsável por despertar o sujeito, seu corpo e seu gozo, para que a sexualidade surja. Neste despertar, o sujeito também quer saber. Surge, assim, o que Freud chamou de pulsão de saber relacionada à curiosidade sexual e à visão.

Ainda em 1905, Freud (1905/1996) nos diz que do olho emana a libido responsável pelo atributo de beleza do objeto sexual. Os olhos são a zona erógena mais afastada do objeto sexual, pontua Quinet (2002), mas, é também aquela que na situação de cortejo pode ser excitada pela qualidade estimuladora da beleza que vê no objeto. É a pulsão escópica que torna um objeto belo e interessante. Esta beleza é um produto. É o produto da sublimação ${ }^{8}$ desta pulsão escópica que, de início, em sua geração espontânea na infância, se dirigia aos genitais, passará a servir à pulsão de saber, à curiosidade sobre o sexo e a diferença anatômica. Para Freud, portanto, a pulsão escópica é constituinte de Eros.

Lacan, por sua vez, sublinha a esquize que há entre olho e olhar e, ainda, a pré-existência do olhar, assinalando, com Merleau-Ponty, que somos olhados no espetáculo do mundo. Isto porque, o sujeito vê desde um único ponto, mas é olhado desde todas as partes. O ponto original da visão não estará, portanto, no corpo, mas no que chama a carne do mundo, uma rede da qual primeiro o sujeito faz parte e, a posteriori, surgirá como olho.

A carne é o conceito que surge para abordar este incorpóreo que não pode existir sem corpo, e que fundamenta o campo escópico. Seus efeitos estão na clínica da psicopatologia cotidiana. De forma perseguidora, este olhar acompanha, por exemplo, um sujeito paranoico. Ele surge e mira o sujeito na psicose, que não suporta o olhar onisciente e onipresente. Ele é também o olhar que sustenta a chamada por Guy Debord (1967) sociedade do espetáculo. O olhar, segundo Lacan (1964/1985, p.104), está do lado de fora, e o que determina o sujeito no campo do visível é, justamente, esse olhar, ou seja, o fato de ser olhado, ser quadro. Isto quer dizer que o olhar, para psicanálise, é um olhar que incide sobre o sujeito.

Esse olhar que pré-existe ao sujeito confirma sua existência, o institui como sujeito, speculum mundi, mas, por outro lado, é algo de inquietante manifestando-se nele, algo que paranoiciza o sujeito, algo ameaçador e violento. Ao ameaçar violentar o sujeito, este precisa inventar seus meios de domar o olhar, por exemplo, criando uma "imagem anteparo", como as lembranças encobridoras a fantasia,

8 A sublimação é um dos quatro destinos da pulsão revelados por Freud. Ela é, em poucas palavras, um meio de satisfazer a pulsão. Freud destacou, com o conceito de sublimação, a plasticidade da libido, seu poder de deslocamento. Para um aprofundamento desta questão, sugerimos o artigo "Percurso freudiano da pulsão", por Attié (1997, p.173-183). 
o quadro, a cena, o sonho9 . A imagem anteparo é um dar-a-ver que pacifica, mas não deixa de apontar o que precisa esconder.

Lacan inventou um objeto lógico para dar conta de certos impasses clínicos e teóricos, tal como a cisão encontrada entre o olho e o olhar. Com tal objeto, articulam-se as pulsões, organiza-se o corpo e o gozo em sua relação com a linguagem. Entre outros objetos que nomeou de $a$, ele destaca o olhar, como veremos. Assim, em Lacan, quando abordamos o tema do olho, encontramos o olhar como objeto da pulsão escópica. Veremos como o autor articula estes dois conceitos.

\section{Valor libidinal do olhar: o véu e a mancha}

O objeto $a$ foi o objeto lógico inventado por Lacan para dar conta das pulsões parciais às quais está subordinado o sujeito. Tributário da Coisa freudiana ${ }^{10}$, esse objeto é o resto da operação de Spaltung, a fenda que divide o sujeito, que vai funcionar como causa do desejo. O sujeito, nos diz Lacan (1964/1998), é lacunar porque, diferente do sujeito do cogito, é um sujeito dividido. Na hiância destas lacunas, o sujeito instaura a função do objeto perdido, objeto $a$, presente na pulsão.

A operação de divisão do sujeito e queda do objeto se dá, para Lacan, na subordinação do sujeito ao significante, portanto, ao Outro do simbólico que antecede o sujeito. Ela é correlata do inconsciente estruturado como uma linguagem. A partir desta cisão, o sujeito barrado estará separado, para sempre, de seu objeto mítico, o objeto perdido desde sempre. Paradoxalmente, ele buscará encontrar este objeto, donde deriva o movimento pulsional.

Vale lembrar que a primeira lista de objetos ligados ao corpo e às zonas erógenas foi feita por Freud. Esta lista constava de três objetos: o seio, o excremento e o falo, aos quais Freud acrescentou, como subcategorias, segundo Brousse (2007), o dinheiro e a criança. Brousse comenta que foi Karl Abraham quem desenvolveu e historicizou esta lista de objetos fazendo corresponder, cada objeto perdido, a um estágio do desenvolvimento pulsional. Os objetos estariam, desta forma, ligados a um desenvolvimento libidinal que supostamente levaria a um grand finale da pulsão genital. Para Brousse, esta era uma maneira de civilizar a criança perversa polimorfa de Freud.

Aos objetos da pulsão, já localizados por Freud, Lacan, acrescenta outros. Os objetos lacanianos parecem mais bizarros, talvez devido a sua influência da clínica da psicose e do próprio surrealismo. Lacan acrescenta a voz e o olhar como objetos, e mais, apesar da importância e especificidade destes dois últimos, ele mostra que pode acrescentar outros, a exemplo da placenta que se perde ao nascer. Para fazer este tipo de exercício Lacan precisa encontrar uma razão entre os objetos, precisa localizar uma função lógica, o ponto comum a qualquer objeto da série.

Assim, a notação algébrica, $a$, existe para nos mostrar a identidade do objeto sob qualquer avatar. Lacan evita, desta forma, usar uma palavra e dar algum sentido ao objeto, evita as flutuações significantes e o sentido figurado. Lacan nos ensina que o objeto $a$ é um pedaço da carne do sujeito, um pedaço de corpo que ele deixará cair. É um objeto separado, escondido e inerte. Para entrar no mundo simbólico, se colocar em relação ao Outro da linguagem, o sujeito dispõe de seus objetos. Neste momento, há perda de um pedaço do corpo e de um pedaço de satisfação, em troca de um lugar

\footnotetext{
9 Vale lembrar como funciona a lembrança encobridora, tipicamente infantil, descrita por Freud em 1888. Nesta, uma memória fantástica, ficcional, a partir de restos mnêmicos, constrói uma cena a fim de proteger o sujeito de algum conteúdo que deve permanecer recalcado. Neste sentido, a lembrança encobridora será, ela também, uma mediadora entre o sujeito e o trauma, ou entre o sujeito e o desejo.

10 A Coisa, Das Ding, destacada por Lacan nas elaborações freudianas, é a coisa irrepresentável, objeto da primeira experiência de satisfação mítica, que causa o interesse libidinal. A Coisa é aquilo que denota o campo do gozo e encontrase em exclusão interna ao sujeito. Deste lugar, apesar de impossível de ser apreendida, ela manifesta-se ao retornar como gozo no sintoma, na perversão e na sublimação. (QUINET, 2002).
} 
simbólico, um lugar na linguagem. Uma vez não operada esta troca inaugural, o sujeito precisará de outros recursos para negociar com o Outro seus objetos.

O objeto $a$ é contornado, em movimento circular, pelas pulsões parciais, ensina Lacan (1964/1998), em movimento que é um impulso que sai de uma borda erógena. No caso da pulsão escópica o olhar é seu objeto e tem o olho como zona erógena. Neste plano, sobre um trajeto de ida e volta, o sujeito é levado a buscar o que não pode ser visto, o que permanece escondido do que se olha, ou seja, o próprio olhar. Lacan afirma que é por este trajeto, erótico, que o sujeito atinge a dimensão do Outro. Isto se esclarece no vai e vem pulsional, e o que se articula, no nível da pulsão escópica, é um se fazer ver. Neste sentido, "a atividade da pulsão se concentra nesse se fazer" (LACAN, 1964/1998, p. 80), e nesse reviramento, ela está encarregada de buscar algo que, a cada vez, responde no Outro, enquanto suporte da pergunta sobre o desejo: 'Que queres?'

O objeto $a$ é o que vem velar a ausência de objeto. Desde Freud, a castração é um efeito da visão da falta de pênis na mãe. O objeto, assim, contém e envelopa a castração, fazendo do falo que falta ao Outro um objeto desejável, ou seja, um objeto causa de desejo. Com a noção de fascinação, Lacan marca, mais uma vez, este lugar particular do olhar. Quando alguém está fascinado por algo, é justamente este alguém, o sujeito, que desaparece. Toda substância subjetiva parece guardar silêncio frente à função do olhar. Este é o ponto zero do olhar, definiu Lacan (1962-63/2005). Para Brousse (2007), neste ponto zero Lacan encontra o valor libidinal do olhar. De um lado, o olhar anula a disjunção entre o objeto $a$ e a falta no Outro. Fascinado, quando o sujeito não é mais que o olhar que completa o Outro, ele neutraliza também, no mesmo golpe, sua falta.

Se o olhar tem a propriedade de tamponar a falta desta forma, é porque é um objeto particularmente agalmático. Brousse (2007) nos lembra que o olhar é capaz de nos conduzir à contemplação, ao apaziguamento, como se não houvesse a castração. É como o olhar da pessoa amada nos momentos apaixonados, ou da mãe e seu bebê: esse olhar que completa e enche a vida de sentido. Nesta perspectiva, o olhar é um véu.

Por outro lado, encontramos o olhar exterior que se materializa na angústia, aquele que não aparece, não se especulariza. Ele é o olhar do espectro, o olhar das casas assombradas, da sensação de ser olhado. Aqui, o objeto lacaniano é tomado por sua face de resto, ele é a mancha que olha. Vale observar que é neste aspecto que o objeto se articula ao desejo. Lacan (1962-63/2005, p. 252) indica que "o desejo ligado à imagem é função de um corte que sobrevém no campo do olho". Ele volta a afirmar que o desejo está ligado a esta função de corte e, consequentemente, a certa relação com a função do resto. Lacan é minucioso: outra coisa é a falta, esta se liga a satisfação.

“O que nos olha?". Esta é uma pergunta de Lacan neste desenvolvimento sobre a pulsão escópica (1962-63/2005, p.277-278). Ele nos conta que seria o branco do olho do cego, por exemplo. É a mancha, o sinal que olha o sujeito, e que mostra como a angústia emerge, na visão, lugar do desejo. Assim, “o objeto $a$ é aquilo que falta, é não especular, não é apreensível na imagem. Apontei-lhes o olho branco do cego como a imagem revelada e irremediavelmente oculta, ao mesmo tempo, do desejo escopofílico". Para Lacan, mais uma vez, é uma oportunidade de dizer que, do lado das coisas, dos objetos, há o olhar; do lado do sujeito, ele vê. Se os olhos não estão aí para ver, estão para se satisfazer. Satisfazer o apetite do olho que, voraz, pode levar a consequências bem sinistras.

\section{A contaminação pelo olho e abertura ao abismo: o véu rasgado do real}

Recorremos, na teoria psicanalítica de Freud e Lacan, a alguns esclarecimentos teóricos que nos servem como suporte para a discussão em torno da cisão do olho e do olhar na História do Olho (1928/2003). Sem esgotar este assunto complexo, buscaremos articular este ponto, a partir da novela, nas próximas linhas.

Para uma melhor compreensão de sua narrativa, vale ainda lembrarmos das construções de Bataille 
(2014) em O Erotismo. Nesse ensaio, Bataille condensa suas elaborações sobre grandes temas de sua obra, em especial, sobre o que entende ser o erotismo. Bataille (2014, p. 35) é contundente: “o erotismo, é possível dizer que é a aprovação da vida até na morte”. Esta não é uma definição do erotismo, mas funciona como uma fórmula que dá o sentido do erotismo para o autor. Ele aproxima, assim, o erotismo e a morte, na medida em que, no erotismo, a vida é levada ao extremo através do gasto inútil de energia, ou seja, da exuberância e do excesso, de maneira tal, que já não se distingue da morte. Bataille entende que, no erotismo, o Eu se perde, a favor da dissolução. Em suas palavras, "O erotismo, já o disse, é a meus olhos o desequilíbrio em que o próprio ser se coloca em questão, conscientemente. Em certo sentido, o ser se perde objetivamente, mas então o sujeito se identifica com o objeto que se perde. Se for preciso, posso dizer, no erotismo: EU me perco" (BATAILLE, 2014, p. 55).

De fato, é este o erotismo que encontramos na Historia do Olho (1928/2003). Ali nos deparamos comum olho que é destituído de sua função ideal - janela da alma, olho de Deus, olho do pai -, para se tornar um objeto de trocas sexuais. Neste intervalo, a pulsão escópica é convocada pelos personagens: ver e ser visto são práticas usuais entre os dois adolescentes, personagens centrais da obra. Bataille mostra que o excesso desta satisfação pulsional, aliada às curiosidades articuladas às angústias sexuais, distanciam o sujeito do desejo para conduzi-lo a um gozo mortífero. Na novela este gozo leva à própria morte, como aconteceu com a doce Marcela e com o desavisado padre. Bataille transgride a função natural do olho, seu significado, para alcançar a ausência semântica que excede o pensamento, em uma provocação que busca contaminar o leitor. Bataille usa os excessos do corpo, e do apetite de ver, presente em seus protagonistas, para mostrar uma série de desdobramentos do objeto olho. O narrador começa olhando o olho do cu de Simone, e termina às voltas com um olho morto, que chora lágrimas de urina.

Para além do olho como zona erógena e da pulsão escópica, a História do Olho coloca em jogo mais um ponto clínico, já que a partir dela podemos ver a função do objeto olhar na fantasia fundamental ${ }^{11}$ do sujeito. Nesta, para além da experiência de júbilo do espelho, onde o infans se reconhece como eu, unidade ideal reconhecida pelo Outro, Lacan percebe o sujeito dividido, faltoso. Isto porque, nesta imagem há algo impossível de ver: o falo enquanto objeto $a$. A partir de então, a busca por algo a ver acossa o sujeito. Neste esforço reiterado de ver, para sempre, o que responde é o olhar. O olhar passa então a funcionar como símbolo da falta, como o que produz a falta. O olho é atraído pela promessa de um saber mais além do visível, por isto Lacan (1965-66) disse que somos atraídos, como moscas no mel, para uma pintura que imite uma cortina, ou uma porta, por exemplo. O sujeito busca o jamais visto, o objeto de uma revelação última.

O sujeito, em geral, frente à falta estrutural que o remete ao desejo, enquadra uma fantasia onde se satisfaz com esta falta. Lacan compara a fantasia com um quadro colocado no lugar de uma janela: essa é a janela que abrimos quando abrimos os olhos e, logo de saída, tomamos distância da realidade, já que um quadro ocupa o espaço. A fantasia, portanto, é este desejo de ver revelada a fantasia. Mas, este desejo deve estar marcado pela impossibilidade, já que, presentificar a fantasia, sem tomar distância dela, é correr o risco de nada mais poder se representar. O quadro em si é uma tomada de distância, um anteparo, enquanto um locus de mediação onde se fabrica e se visualiza imagens. Por isto a fantasia é um protótipo do quadro, em Lacan. Para Foster (2005, p.170), "ver sem o anteparo seria deixar cegar-se pelo real". A intenção de Bataille era a de ser cegado, rasgar o véu da significação pela obscenidade, para cair no não-senso e atingir a sensibilidade fora da linguagem.

A partir de um frenesi funesto e único, na História do Olho (1928/2003) a falta de sentido, o

11 A fantasia é um conceito importante e complexo da teoria psicanalítica. Em breves palavras, a fantasia fundamental é o que articula a relação do sujeito com o Outro e, desta forma, sustenta o desejo. Ela é portadora de uma lógica que funciona, para cada sujeito, como uma escrita que se repete a partir de uma invenção feita, durante o Complexo de Édipo, para lidar com a castração. 
impossível, a mancha cega, são nomes para a morte, ou para o real. Há um sentimento de tragédia e melancolia sob o fundo obsceno. Um assombramento diante "das coisas do sexo" (BATAILLE, 2003, p. 25), sorte de abertura para o abismo.

Na novela, o autor escreve o movimento do objeto $a$. Bataille não só faz os deslocamentos e as conexões dos avatares do objeto como mostra que o objeto se move, e nunca está onde deveria. $\mathrm{O}$ objeto, a princípio, está entre: como na primeira cena da novela, está entre os cortes das meias e do avental de Simone, entre o leite e o prato, entre o grito e o olho morto, entre as pálpebras e as pernas, entre a morte e o sexo. Ou está no rubor de Marcela, no sol da Espanha, na luz da lua e da urina, no olhar ávido de Simone. O narrador, contaminado pela mulher, busca o encontro massivo com este objeto para alcançar este gozo sublime e obsceno que vê em Simone, a "santa do abismo", ou em Marcela, corpo fragmentado que não suportou os prazeres fora do armário.

A insaciabilidade e a violência dos personagens da novela buscam a desintegração e uma despersonalização, uma perda das formas que levaria a uma dissolução dos seres na natureza, um retorno aos elementos primevos. Por fim, só resta a carne, o informe, e o objeto em sua crueza. O padre se arruína depois de ser medusado pelo objeto que vê na vulva de Simone. Simone se apodera dos objetos para provocar o olhar e a angústia, violando qualquer anteparo. O olhar, na novela, é sexualizado, ereto, para depois ver além, exceder o voyerismo e se tornar voyant. (TEIXEIRA, 2005). O narrador, no último momento, está anulado pela presença maciça deste objeto, que quebrou a distância entre o sexo e o olhar, ponto culminante do horror.

Levantando-me, afastei as coxas de Simone: ela jazia no chão, de lado; encontrei-me então diante daquilo que - imagino - eu sempre esperara: assim como a guilhotina espera a cabeça que vai decepar. Meus olhos pareciam estancados de tanto horror; vi na vulva pelada de Simone, o olho azul-pálido de Marcela a me olhar, chorando lágrimas de urina. (BATAILLE, 2003, p.85).

Ao usarmos os desenvolvimentos de Lacan, relativos ao olhar no Seminário 13 (1965-66), para ler a montagem batailleana, percorremos algumas noções caras a teoria psicanalítica, em especial, as noções de objeto olhar e de pulsão escópica. Mas, além disto, percebemos que a História do Olho não cria uma narrativa anteparo. Ou seja, se o autor chega a provocar o olhar, uma das funções do anteparo, não é para domesticá-lo, mas para usá-lo como um instrumento pungente, de corte, capaz de furar o véu, o drama da representação e da narrativa. Com esta estratégia ele visa rebaixar os ideais e o ilusório, convocando o sujeito a se apresentar em outro lugar, diferente daquele lugar acomodado da representação clássica.

Bataille queria a imagem ao avesso, ou seja, fazer o real existir em toda sua glória soberana, ou em sua abjeção crua e horrível. Ele sabia que era preciso destituir as significações vinculadas ao anteparo e ir além do princípio do prazer: Ele estava disposto. A operação se faz, portanto, neste nível: de sujeito-objeto a ser visto pelo Outro, assujeitado ao Outro que olha (realidade como efeito de representação), para sujeito ao olhar-do-objeto (real como trauma). Em Bataille, o olho, objeto obsceno, aparece pulsante a serviço do real, causando estranhamento ao deslocar o mundo assentado das coisas.

O que descobrimos, entretanto, com os desenvolvimentos de Lacan sobre o olhar, é que, na fantasia, romper o anteparo não é para qualquer um! Mesmo assim, o real sempre estará um passo atrás da representação e a imagem, por mais obscena e devastadora que seja, funcionará para ludibriar o sujeito, por mais que a estrutura seja forçada. O que encontramos, nesse caminho pesquisado, e na História, são os rastros deste real que retornam, eclodindo ao acaso. 


\section{Referências}

ASSANDRI, José. Entre Bataille e Lacan: Ensayo sobre el ojo, golosina caníbal. Cidade del Mexico: Ediciones literales, 2007.

ATTIÉ, J. Percurso freudiano da sublimação. In: RIBEIRO, Maria A. C., MOTTA, Manoel B. Os destinos da pulsão. Contra Capa Livraria, Rio de Janeiro, 1997.

BATAILLE, Georges. O ânus solar (e outros textos do sol). Lisboa: Assírio e Alvim, 2007.

BATAILLE, Georges. O olho pineal. In: BATAILLE, Georges. O ânus solar (e outros textos do sol). Lisboa: Assírio e Alvim, 2007.

BATAILLE, Georges. História do olho (1928). Tradução de Eliane Robert Moraes. 2ed, São Paulo: Cosac e Naif, 2004.

BATAILlE, Georges. O Erotismo. Tradução de Fernando Scheibe. Belo Horizonte: Autêntica Editora, 2014.

BROUSSE, M-Hélène. Objets étranges, objets immatériels :porquoi Lacan inclut la voix et le regard dans la serie des objets freudiens? In: Arquivos Brasileiros de Psicologia. V. 59, n.2, 2007.

FOSTER, Hal. O retorno do real. In: Concinnitas. Ano 6, vol.1, n.8, jul. 2005.

FREUD, Sigmund. Três ensaios sobre a sexualidade (1905) In: FREUD, Sigmund. Obras psicológicas completas de S. Freud: edição standard brasileira.

FREUD, Sigmund. (1910) A concepção psicanalítica da perturbação psicogênica da visão. In: FREUD,Sigmund. Obras psicológicas completas de S. Freud: edição standard brasileira. Vol. XI, P.217-229.

FREUD, Sigmund. O Estranho (1919). In: FREUD, Sigmund. Obras psicológicas completas de Sigmund Freud: edição standard brasileira. v. XVII. p. 235-276.

LACAN, Jacques. O Seminário, livro10: A angústia (1962-63). Tradução de Vera Ribeiro. Rio de Janeiro: Jorge Zahar, 2005.

LACAN, Jacques. O Seminário, livro11: os quatro conceitos fundamentais da psicanálise (1964). Tradução de M. D. Magno. Jorge Zahar Ed., 1998.

LACAN, Jacques. O Seminário, livro13: O objeto da psicanálise. (1965-66) Texto não estabelecido $[\ldots]$.

QUINET, Antonio. Um olhar a mais: ver e ser visto na psicanálise. Rio de Janeiro, Jorge Zahar Ed., 2002. 
